\title{
Aquaculture and ocean stewardship
}

\author{
This article belongs to Ambio's 50th Anniversary Collection. Theme: Solutions-oriented \\ research
}

\author{
Carl Folke, Nils Kautsky
}

Published online: 14 March 2021

In the mid-1980s contemporary aquaculture had emerged as a new way of producing seafood. It was often portrayed as a new technology that would replace overfished stocks and make humankind independent of nature's fluctuations. Triggered by such claims, we decided to investigate the fast expanding aquaculture industry, which resulted in the 1989 Ambio paper 'The role of ecosystems for a sustainable development of aquaculture' (Folke and Kautsky 1989).

We were fascinated about similarities of this fast growing sector with earlier approaches in natural resource management founded on the belief that it is doable to fully replace natural capital with human-made capital-perfect substitution - an idea which at that time was deeply rooted in several parts of society. Inspired by scholars like Odum (1989) and Boulding (1966), who beautifully had illustrated that humanity is dependent on the life-supporting ecosystems, we quantified and clarified the significance of nature's contributions to the rapidly expanding industry. Our paper showed that despite this new way of producing seafood, the industry's success still rested on the work of marine food webs and ecosystems and that this should be accounted for in the development of the industry. Hence, one of the main messages was that perfect substitution between nature and society through technological change is an illusion not anchored in reality, a fact that has become abundantly clear today. Later, the term 'the pathology of natural resource management' was coined to describe this phenomena (Holling and Meffe 1996; Sterner et al. 2006).

Furthermore, our paper stressed the unsustainability of 'throughput systems' of production, that is, systems of production that uses a lot of input and generates a lot of waste (Daly 1990; Larsson et al. 1994; Ghisellini et al. 2016) and thus put pressure on the environment (Arrow et al. 1995). This was the case in the early days of salmon farming. In the 1989 paper, we pleaded for more integrated and circular aquaculture systems. In later papers, together with Max Troell, we dived deeper into contemporary aquaculture and the waste issues, including the use of antibiotics (Folke et al. 1994; Kautsky et al. 2000; Henriksson et al. 2018). At that time, these papers provoked strong reactions from both scientists, farmers, and policy makers involved with aquaculture. Nowadays, the necessity of circularity and a circular economy is widely endorsed in practice, policy, and business in the aquaculture sector and society in general.

What is exciting is that our early work sparked interest and long-lasting collaborations around aquaculture and seafood production with colleagues in many different parts of the world. For example, we fondly recall the exciting collaboration to which Hal Mooney at Stanford took the initiative. In the late 1990s, Roz Naylor and Becky Goldburg had become interested in aquaculture-environment interactions and together we invited Jurgenne Primavera, Malcolm Beveridge, Jason Clay, and Jane Lubchenco to a set of workshops. One of the articles resulting from these workshops, 'Effect of aquaculture on world fish supplies' (Naylor et al. 2000), a global analysis and synthesis of the impacts of aquaculture on ecosystems and fish supplies, serves as a reflection of the collaboration and is still a classic and has been listed as such by Nature. More recent ones include 'Does aquaculture add resilience to the global food system?' (Troell et al. 2014) 'China's aquaculture and the world's wild fisheries' (Cao et al. 2015). The current work with 'The Blue Food Assessment' is another example of the lasting collaboration. Here, the focus is to identify, review and fill important gaps in our understanding of the role of aquatic foods in global food systems now and in the future, as well as to inform and propel change in the policies and practices that will shape decisions which 
impact the future of food (www.bluefood.earth). The full Blue Food Assessment will be released ahead of the 2021 UN Food Systems Summit.

Over the course of the last decades, the work with our colleagues and many other researchers in the aquaculture field, has helped to motivate industry improvements on feed efficiency and sustainable farming practices. Perhaps the most striking example, is the SeaBOS initiative. It all started with the discovery of about a dozen seafood companies as Keystone Actors in the Anthropocene Ocean. We showed that these transnational corporations controlled about $15 \%$ of the global marine seafood catch and some $20-40 \%$ of the largest and most valuable stocks, including species that play important roles in their respective ecosystem. Furthermore, the Keystone Actors dominate all segments of seafood production, operate through extensive global networks of subsidiaries and are profoundly involved in fisheries and aquaculture decision-making. We proposed that sustainability leadership by such Keystone Actors could result in cascading effects throughout the entire seafood industry and possible enable a much needed transition towards improved management of marine living resources and ecosystems (Österblom et al. 2015; Jouffray et al. 2019).

Now, since 2016, we have been closely collaborating with ten of these Keystone Actors, first through the Keystone Dialogues and more recently through the Seafood Business for Ocean Stewardship (SeaBOS) initiative that emerged from the dialogues. Interestingly, the SeaBOS collaboration involves some of the largest aquaculture and feed companies in the world. Hence, issues that we raised some thirty years ago in Ambio are now on the table in this science-business collaboration with a focus on sustainable development and ocean stewardship!

The SeaBOS initiative is an expression of interest from industry to explicitly test the hypothesis that a small minority of powerful actors can influence a majority of smaller actors, thereby potentially causing a cascading shift in the industry towards ocean stewardship. The scientific work is orchestrated by a team of scientists at the Stockholm Resilience Centre, Stockholm University with support from US philanthropists, as well as the Beijer Institute of Ecological Economics and the Global Economic Development and the Biosphere program (GEDB) of the Royal Swedish Academy of Sciences.

For the first time, the initiative connects the global seafood business to science, connects wild capture fisheries to aquaculture, and connects European and North American companies to Asian companies. The ambition is to lead a global transformation towards sustainable seafood production and a healthy ocean. A key factor catalyzing the establishment of SeaBOS has been the active engagement of HRH Crown Princess Victoria of Sweden with a deep interest in ocean issues and her role as a United Nations
Sustainable Development Goals Advocates Alumni (Österblom et al. 2017).

In SeaBOS, we are performing science for change, a trust-building collaborative effort with co-production of knowledge and understanding, drawing on the best science to date and combining it with competencies and skills of the transnational aquaculture and fisheries corporations to move towards common goals. We, as scientists, serve as honest brokers, providing the state-of-the-art science to clarify, motivate and inspire the companies to perform towards sustainable ocean futures. Company participation in SeaBOS is at the CEO-level in recognition that for principles of ocean stewardship to be embedded across all operations in a transnational corporation, there must be commitment from the leadership. Leadership also requires collaboration with science, policy, and civil society.

Collaborative task forces are currently one of the key mechanisms within SeaBOS for translating its vision and commitments into actions and results. So far, six task forces have been established, each comprised of operational staff from multiple SeaBOS companies and as well as scientists (Fig. 1). Each task force is supported in its work with scientific input in the form of scientific background briefs (www.keystonedialogues.earth). Progress to date include SeaBOS occupying a central place in the corporate reporting by member companies, there is now sustainability reporting performed by all the companies, the values of shared learning and collaborative actions is acknowledged, strategic partnerships have been established to amplify and progress the SeaBOS vision, and SeaBOS has started to operate as a policy influencer towards ocean stewardship.

Producing seafood requires healthy oceans. In the Anthropocene, this cannot be taken for granted (Lubchenco and Gaines 2019; Jouffray et al. 2020). Seafood companies seem to be at the forefront among ocean-based industries in reaching the stage of understanding the complete reliance of their operations on a healthy biosphere. As recently stated in a speech by one of the CEOs of the SeaBOS initiative "It is really this simple-there is no seafood industry in a dead ocean. We engage in ocean stewardship not only because we WANT to but because we HAVE to." Active stewardship for healthy oceans is a necessity. Clearly, the ocean stewardship challenge generates a new purpose of contributing to the larger goal of global sustainability for humankind.

Well over 30 years ago, we demonstrated the role of ecosystems for a sustainable development of aquaculture. Now, seafood businesses and other sectors engaged in the oceans call for transformations towards ocean stewardship (UN Global Compact 2020 https://www.unglobalcompact. org/). Over the years, as scientists, our research group has expanded the scope of science from identifying an issue, to developing understanding of the broader system, and now 


\section{The task forces of SeaBOS}

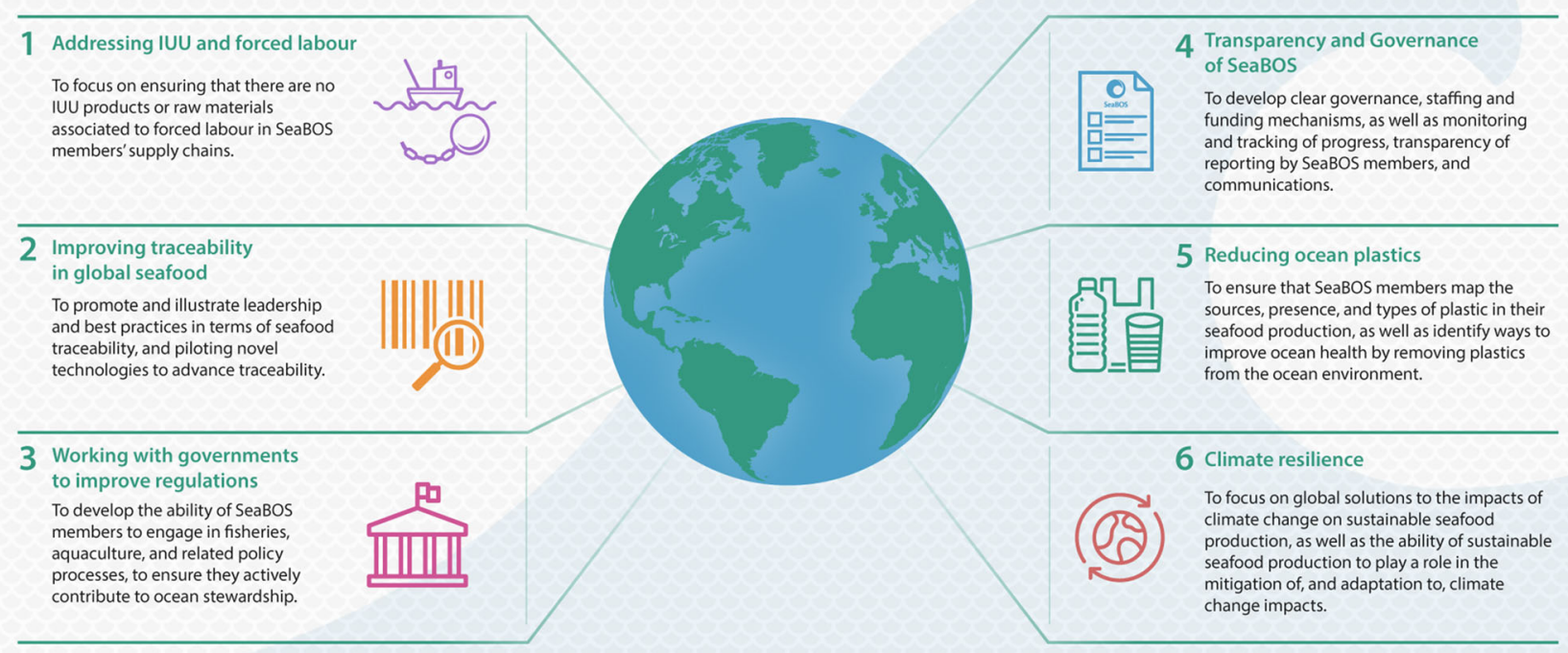

Fig. 1 The six current task forces of the SeaBOS initiative (www.keystonedialogues.earth)

acting as science-based systemic change makers in collaboration with the keystone actors as well as the broader context within which they operate (Österblom et al. 2017) such as engaging with e.g. the High-Level Panel for a Sustainable Ocean Economy (www.oceanpanel.org) or Friends of Ocean Action (www.weforum.org/friends-ofocean-action). This is inspiring, and reflects new narratives of hope for action, narratives that reconnect development to the biosphere foundation and the necessity of transformations towards sustainable futures (Folke et al. 2011, 2019). The circle is closed!

\section{REFERENCES}

Arrow, K., B. Bolin, R. Costanza, P. Dasgupta, C. Folke, C.S. Holling, B.-O. Jansson, S. Levin, et al. 1995. Economic growth, carrying capacity, and the environment. Science 268: 520-521.

Boulding, K.E. 1966. The economics of the coming spaceship Earth. In Environmental quality in a growing economy, ed. H. Jarrett, 3-14 Resources for the Future/Johns Hopkins University Press, Baltimore, Maryland, USA.

Cao, L., R. Naylor, P. Henriksson, D. Leadbitter, M. Metian, M. Troell, and W.B. Zhang. 2015. China's aquaculture and the world's wild fisheries. Science 347: 133-135.

Daly, H.E. 1990. Sustainable development: From concept and theory to operational principles. Population and Development Review 16: $25-43$.

Folke, C., and N. Kautsky. 1989. The role of ecosystems for a sustainable development of aquaculture. Ambio 18: 234-243.
Folke, C., N. Kautsky, and M. Troell. 1994. The costs of eutrophication from salmon farming: Implications for management. Journal of Environmental Management 40: 173-182.

Folke, C., Å. Jansson, J. Rockström, P. Olsson, S.R. Carpenter, F.S. Chapin, A.-S. Crepín, G. Daily, et al. 2011. Reconnecting to the Biosphere. Ambio 40: 719-738.

Folke, C., H. Österblom, J.-B. Jouffray, E.F. Lambin, W.N. Adger, M. Scheffer, B.I. Crona, M. Nyström, et al. 2019. Transnational corporations and the challenge of biosphere stewardship. Nature Ecology \& Evolution 3: 1396-1403.

Ghisellini, P., C. Cialani, and S. Ulgiati. 2016. A review on circular economy: The expected transition to a balanced interplay of environmental and economic systems. Journal of Cleaner Production 114: 11-32.

Henriksson, P.J.G., A. Rico, M. Troell, D.H. Klinger, A.H. Buschmann, S. Saksida, M.V. Chadag, and W.B. Zhang. 2018. Unpacking factors influencing antimicrobial use in global aquaculture and their implication for management: A review from a systems perspective. Sustainability Science 13: $1105-1120$.

Holling, C.S., and G.K. Meffe. 1996. Command and control and the pathology of natural resource management. Conservation Biology 10: 328-337.

Jouffray, J.-B., R. Blasiak, A.V. Norström, H. Österblom, and M. Nyström. 2020. The blue acceleration: The trajectory of human expansion into the ocean. One Earth 2: 43-54.

Jouffray, J.-B., B. Crona, E. Wassenius, J. Bebbington, and B. Scholtens. 2019. Leverage points in the financial sector for seafood sustainability. Science Advances 5: eaax3324.

Kautsky, N., P. Rönnbäck, M. Tedengren, and M. Troell. 2000. Ecosystem perspectives on management of disease in shrimp pond farming. Aquaculture 191: 145-161.

Larsson, J., C. Folke, and N. Kautsky. 1994. Ecological limitations and appropriation of ecosystem support by shrimp farming in Colombia. Environmental Management 18: 663-676. 
Lubchenco, J., and S.D. Gaines. 2019. A new narrative for the ocean. Science 364: 911.

Naylor, R., R. Goldburg, J. Primavera, N. Kautsky, M. Beveridge, J. Clay, C. Folke, J. Lubchenco, et al. 2000. Effect of aquaculture on world fish supplies. Nature 405: 1017-1024.

Odum, E.P. 1989. Ecology and our endangered life-support systems. Sunderland: Sinauer.

Österblom, H., J.-B. Jouffray, C. Folke, B. Crona, M. Troell, A. Merrie, and J. Rockström. 2015. Transnational corporations as keystone actors in marine ecosystem. PLoS ONE 10: e0127533.

Österblom, H., J.-B. Jouffray, C. Folke, and J. Rockström. 2017. Emergence of a global science-business initiative for ocean stewardship. Proceedings of the National Academy of Sciences, USA 114: 9038-9043.

Sterner, T., M. Troell, J. Vincent, S. Aniyar, S. Barrett, W. Brocks, S.R. Carpenter, K. Chopra, et al. 2006. Quick fixes for the environment: Part of the solution or part of the problem? Environment 48: 20-27.
Troell, M., R. Naylor, M. Metian, M. Beveridge, P. Tyedmers, C. Folke, H. Österblom, A. de Zeeuw, et al. 2014. Does aquaculture add resilience to the global food system? Proceedings of the National Academy of Sciences, USA 111: 13257-13263.

Publisher's Note Springer Nature remains neutral with regard to jurisdictional claims in published maps and institutional affiliations.

\section{Carl Folke ( $\square)$}

Address: Stockholm Resilience Centre, Stockholm University, Stockholm, Sweden.

Address: Beijer Institute, Royal Swedish Academy of Sciences, Stockholm, Sweden.

e-mail: carl.folke@beijer.kva.se

\section{Nils Kautsky}

Address: Department of Ecology, Environment and Plant Science, Stockholm University, Stockholm, Sweden. 